\title{
120 years of investigations on zoobenthos in the southern Baltic
}

\author{
L. Żmudzinski \\ Marine Biology Centre; Sw. Wojciecha Str. 5, 81-347 Gdynia, Poland \\ and \\ University of Education; Arciszewskiego Str. 22, 76-200 Słupsk, Poland
}

\begin{abstract}
The scheme of macrozoobenthos research development in the southern region of the Baltic Proper is presented here. In the course of a 120 -year-long investigation cycle, four different, partly overlapping periods can be distinguished: qualitative investigations, quantitative distribution studies, biomass investigations, and regular monitoring of zoobenthos.
\end{abstract}

\section{INTRODUCTION}

The southern Baltic macrobenthic investigations were initiated by a German scientist, Karl Möbius, in 1871. The first hundred years witnessed only irregular examinations in which the year and area were randomly chosen. As late as the 1970s, systematic observations of the Baltic macrozoobenthos were started, which were partly coordinated to meet the Helsinki Convention regulations.

Macrobenthos research can be divided into four partly overlapping periods according to benthos-sampling performance methods: qualitative and quantitative investigations, biomass investigations, and regular monitoring.

\section{QUALITATIVE INVESTIGATIONS}

The first investigation of the southern Baltic macrobenthic invertebrate composition was carried out in 1871. During the expedition of a German research vessel "Pommerania" in 1871, Karl Möbius collected bottom macroinvertebrates along some profiles across selected Baltic Sea areas (Fig. 1). In the southern Baltic, however, the profiles run off the deepest parts of particular deeps, going along their edges rather than across them. This included some shallows important for the fisheries. There Möbius took benthos samples from 55 stations (Table 1 ).

In 1880, Meyer and Möbius (1882) examined the species composition and distribution of macrozoobenthos in the western region of the Gulf of Gdańsk, known as Puck Bay (Fig. 1). It is a shallow area; the deepest station fixed at the edge of the Gdansk Deep has a depth of $67 \mathrm{~m}$. Some years later (in 1893), Brandt collected bottom invertebrates from the Baltic Sea which included some areas from the southern Baltic.

The next bottom macrofauna investigation in the open waters of the southern Baltic Sea was carried out by Reibisch (1902) who, in 1901, took samples from over 10 stations situated mainly on the shallower Baltic grounds important for the fishery (Fig 2). 


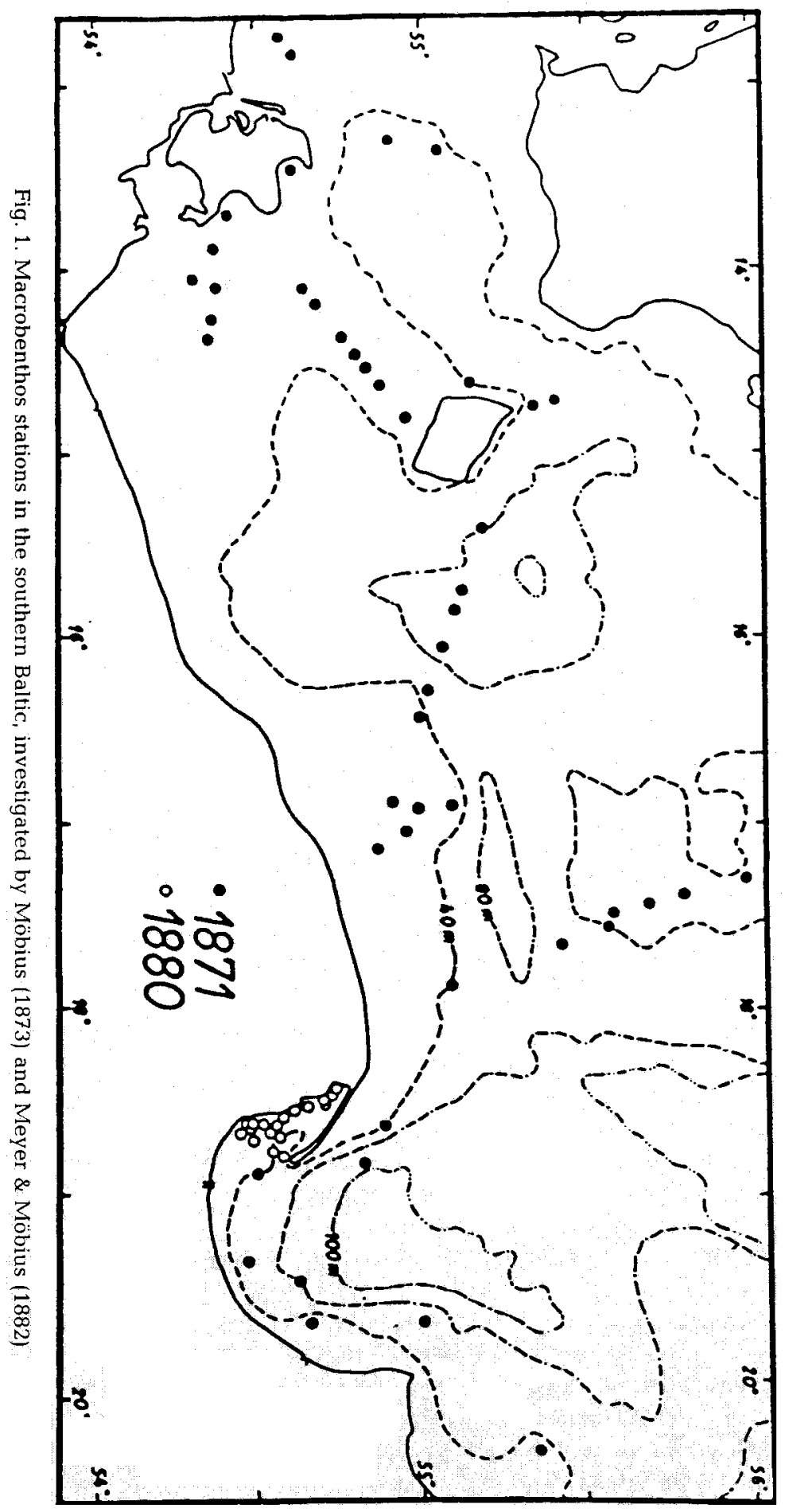


Table 1. Number of macrobenthic stations during the period of qualitative investigations in the southern Baltic. $\mathrm{x}$ - up to 5 stations, $\mathrm{xx}$ - up to 15 stations, $\mathrm{xxx}$ - up to 25 stations, $\mathrm{xxxx}$ - over 25 stations

\begin{tabular}{|c|c|c|c|c|c|c|c|c|}
\hline \multirow[t]{2}{*}{ Author } & \multirow[t]{2}{*}{ Years } & \multirow[b]{2}{*}{ Arcona } & \multirow[b]{2}{*}{$\begin{array}{l}\text { Born- } \\
\text { holm }\end{array}$} & \multicolumn{2}{|l|}{ Basins } & \multirow[b]{2}{*}{ Gotland } & \multicolumn{2}{|c|}{$\begin{array}{c}\text { Number of } \\
\text { stations }\end{array}$} \\
\hline & & & & Slupsk & Gdańsk & & $\begin{array}{l}\text { Below } \\
40 \mathrm{~m}\end{array}$ & Total \\
\hline Möbius & 1871 & $\mathrm{xx}$ & $\mathrm{xx}$ & $\mathbf{x x}$ & $x \mathbf{x}$ & $\mathrm{x}$ & 18 & 55 \\
\hline Meier, Möbius & 1880 & & & & $\mathrm{xxx}$ & & 5 & 18 \\
\hline Reibisch & 1901 & $\mathrm{x}$ & $\mathrm{x}$ & $\mathbf{x}$ & $\mathrm{x}$ & $\mathbf{x}$ & 5 & 14 \\
\hline Heinen ${ }^{*}$ & $1903-10$ & $\mathbf{x}$ & $\mathrm{x}$ & & & & 3 & 7 \\
\hline Skorikow & 1908 & $\mathrm{x}$ & $\mathrm{x}$ & & & $\mathrm{x}$ & 4 & 5 \\
\hline Demel & 1924 & & & & $\operatorname{xxxx}$ & & 10 & 44 \\
\hline Demel & $1932-35$ & & & & $\operatorname{xxxx}$ & & 15 & 64 \\
\hline Seifert & $1936-37$ & & $\mathrm{xxxx}$ & & & & & 36 \\
\hline Forsman & $1953-54$ & & $\mathrm{xx}$ & & & & 13 & 14 \\
\hline Jażdżewski & 1961 & & & & $\operatorname{xxxx}$ & & & 26 \\
\hline Total & & & & & & & 73 & 283 \\
\hline
\end{tabular}

At the end of the 19th century and in the first decade of this century, three other qualitative investigations were carried out on the zoobenthos. These dealt with the geographical distribution of worms, mainly polychaetes, in the Baltic Sea, and they throw some light upon the interspecific relationships at that time. Michaelsen (1896), Skorikow (1910) and Heinen (1919) analysed the range of particular species in the Baltic Sea, including its southern region, or at least the southwestern strip.

In the 1920 s and 1930 s, relatively thorough fauna investigations were carried out on two sheltered coastal areas, especially the Greifswalder Bodden (Seifert, 1938), and Puck Bay (Demel, 1925, 1935), as far as along the southeastern region of the Baltic Sea (Lundbeck, 1929; Sklower, 1930). Somewhat later, very interesting fauna research was done off the Kalmarfjord and in the neighbouring parts of the Bornholm Basin (Forsman, 1956) as well as in Puck Bay (Jażdżewski, 1962, 1971).

As the evidence shows in the first research period - the qualitative one - the southern Baltic zoobenthos investigations were started by the Germans, who were followed by the Russians, the Poles, and finally the Swedish researchers.

At the time of the qualitative research, the bottom fauna samples were collected by means of bottom dredging devices of which no published description or diagram was included. Karl Möbius $(1873,1884)$ called the device "die Kurre". Until the beginning of this century, no exact geographical position had been stated; only some indirect location had been given according to the distances from lighthouses or other distinct onshore points.

\section{QUANTITATIVE INVESTIGATIONS}

These investigations of bottom macrofauna began in the first decade of this century by a Danish scientist Petersen (1914) - the inventor of the first bottom grab; later called 


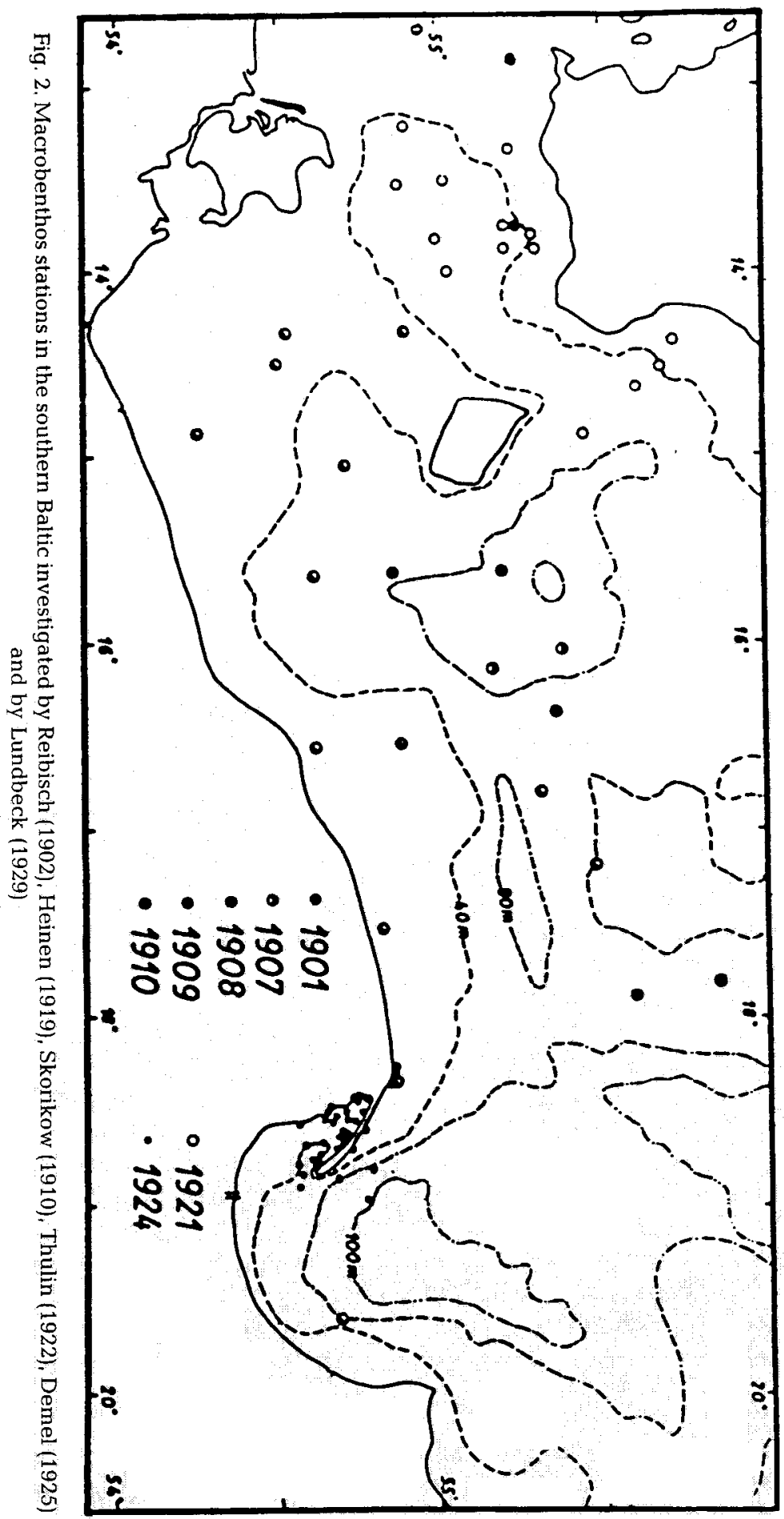


"Petersen's Bottom Grab". Petersen confined his research to Danish waters including only a tiny part of the Baltic Proper, i.e. the western edges of the Arcona Basin (Petersen \& Jensen, 1911). The Swedish scientists, Thulin (1922) \& Hessle (1924) conducted quantitative macrobenthic quantitative investigations which were extended to cover the whole of the Arcona Basin and northwest region of the Bornholm Basin (Fig. 2).

During the years 1932-1938 Mulicki (1938) examined the quantitative distribution of bottom macrofauna in the western part of the Gulf of Gdańsk (Fig. 3), having obtained samples from 72 stations (Table 2). Benthos samples were collected by means of a smaller bottom grab, known as the "Ekman Grab".

At the end of the 1930s and in the second half of the 1940s, a team of Polish biologists were the first to examine the Baltic Sea benthos using diving equipment, i.e. a diving helmet of their own construction. While diving several times in Puck Bay, they collected 40 samples per $0.25 \mathrm{~m}^{2}$, each time taking them directly from the bottom surface (Bursa et al., 1939; Bursa, 1948; Wojtusiak et al., 1950, 1951). During these investigations one could take into account not only soft bottoms (sandy and muddy) but also rocky and stony ones. The research results were presented in very picturesque illustrations, similar to those made by Petersen, the pioneer of the benthos quantitative investigations (Fig. 4).

It seems that, in the second research period of the Baltic Sea zoobenthos, various methods of benthos sampling were used. This period covered mainly the first decade, and the 1930s and 1940s of this century, significantly overlapping with the first and the third periods of the macrobenthic investigations.

\section{BIOMASS INVESTIGATIONS}

The third period of southern Baltic zoobenthos research was started by a German scientist, Hagmeier $(1926,1930,1987)$ and concentrated not only on species composition records but on the biomass and abundance of bottom macrofauna as well. In the years 1925, 1929 and 1931, Hagmeier collected samples of bottom macrofauna from about 200 stations in the southern Baltic Sea, reporting the total biomass of zoobenthos from each station (Rumohr, 1987). Unfortunately, Hagmeier was interested in a trendy problem at that time. The results of the zoobenthos species distribution often reported only the dominant species at particular stations, not always stating the abundance, let alone the biomass of individual species or of the total macrobenthos.

In 1948-1954, Demel \& Mańkowski (1951), and Demel \& Mulicki (1954, 1959) commenced a series of macrozoobenthic investigations in the southern Baltic Sea which was repeated every couple of years. The results gave a great number of samples collected from 272 stations located fairly evenly over all the area, $83 \%$ of them distributed at the depth of over $40 \mathrm{~m}$ (Table 3 ). This resulted in a number of maps showing the distribution of dominant species and general macrobenthos biomass.

Based on this material, Mulicki $(1957,1959,1962)$ could establish the ecological demands of basic bottom invertebrate species. He analysed their occurrence related to temperature, salinity and oxygen in near bottom water and also to depth range and bottom type. The research was a classical one, rarely to be repeated.

In 1956 and 1957, Mulicki \& Żmudziński (1969) returned to the problem of distribution and biomass of bottom macrofauna in the southern Baltic Sea, thus discovering vast benthos deserts in the Bornholm Deep and the Gdańsk Deep. Löwe (1963) analvsed 


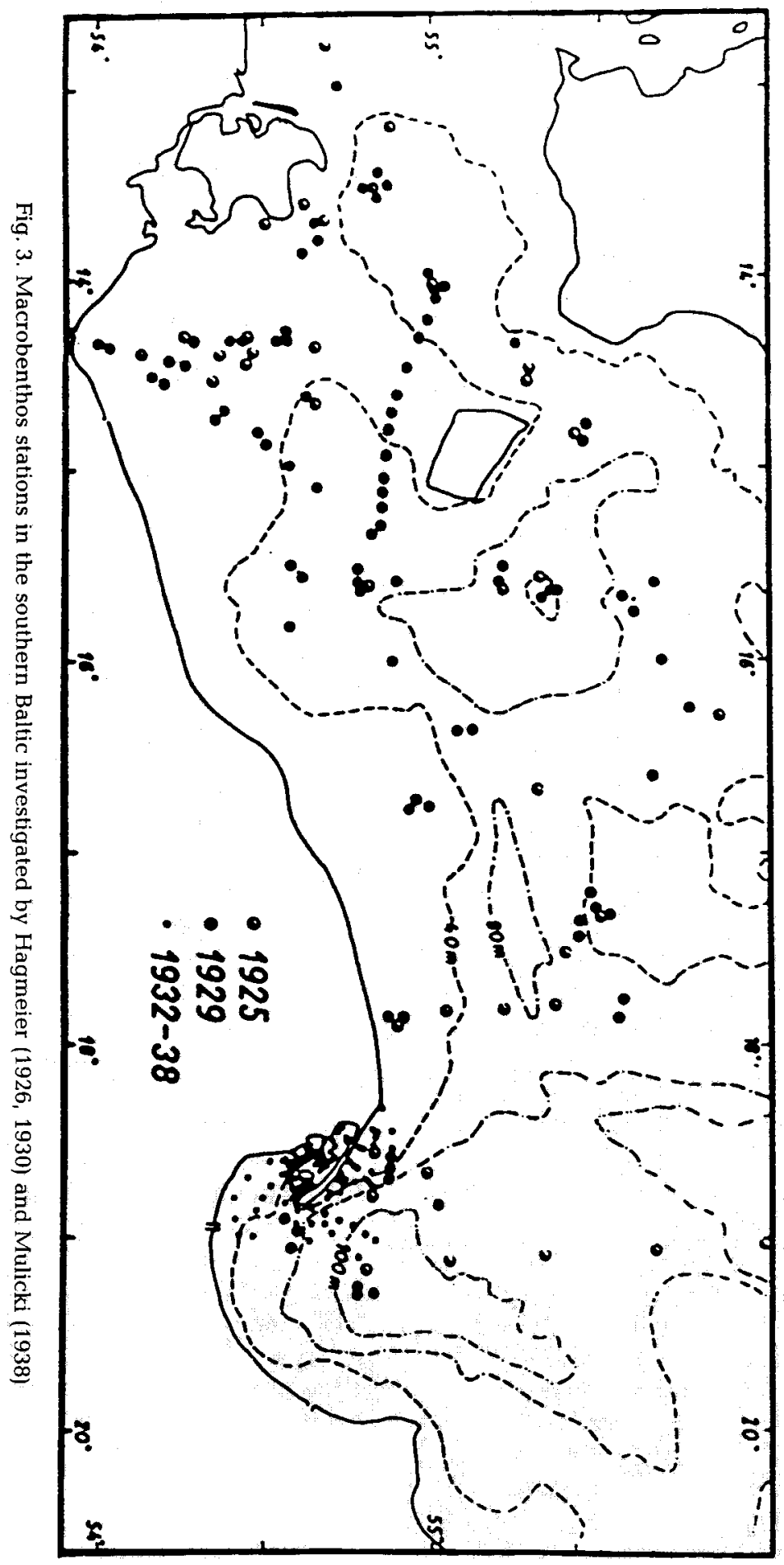


Table 2. Number of macrobenthic stations during the period of quantitative investigations in the southern Baltic. For meaning of symbols see legend to Table 1

\begin{tabular}{|c|c|c|c|c|c|c|c|c|}
\hline \multirow[t]{2}{*}{ Author } & \multirow[t]{2}{*}{ Years } & \multirow[b]{2}{*}{ Arcona } & \multirow[b]{2}{*}{$\begin{array}{l}\text { Born- } \\
\text { holm }\end{array}$} & \multirow{2}{*}{$\begin{array}{l}\text { Basins } \\
\text { Slupsk }\end{array}$} & \multirow[b]{2}{*}{ Gdańsk } & \multirow[b]{2}{*}{ Gotland } & \multicolumn{2}{|c|}{$\begin{array}{c}\text { Number of } \\
\text { stations }\end{array}$} \\
\hline & & & & & & & $\begin{array}{c}\text { Below } \\
40 \mathrm{~m}\end{array}$ & Total \\
\hline Petersen, Jensen & 1911 & $\mathrm{x}$ & & & & & & 2 \\
\hline Thulin & 1921 & $x x$ & $\mathrm{x}$ & & & & 10 & 14 \\
\hline Mulicki & $1935-38$ & & & & $\mathrm{xxxx}$ & & 18 & 72 \\
\hline Bursa et al. & 1938 & & & & $\mathrm{xx}$ & & & 9 \\
\hline Bursa et al. & 1939 & & & & $\mathrm{xx}$ & & & 11 \\
\hline Wojtusiak et al. & 1946 & & & & $\mathrm{xx}$ & & & 10 \\
\hline Wojtusiak et al. & 1948 & & & & $\mathrm{xx}$ & & & 10 \\
\hline Total & & & & & & & 28 & 128 \\
\hline
\end{tabular}

bottom macrofauna stocks at about the same time in the Arcona and in part of the Bornholm Basins by drawing samples from 177 stations. This encompassed a high density of sampling points, as the area is not large (Table 3). In the 1960s and 1970s, interesting changes in the occurrence of zoobenthos in the Bornholm Deep were observed by Leppäkoski $(1969,1975)$, and in the whole southern Baltic by Żmudziński $(1968,1971$, 1976).

In the 1960s, Żmudziński $(1967,1968,1971,1976,1982)$ and Ostrowski \& Żmudziński (1982) performed a huge job, investigating southern Baltic macrozoobenthos by taking samples from over 900 stations; $41 \%$ of the samples were taken from a depth of over $40 \mathrm{~m}$ (Table 3). This research was continued in the seventies by a number of scientists including Andersin et al. (1977, 1978), Järvekülg (1979), Żmudziński \& Osowiecki (1991), and others.

\section{REGULAR MONITORING}

Towards the end of the 1970 s, systematic environmental monitoring was introduced, meeting the regulations of the Helsinki Convention. This meant the contribution of many, partly anonymous, scientists to southern Baltic macrobenthos investigations. Macrobenthos samples collected twice a year, as well as other macrobenthos material, enabled the issues of sections on benthos in "Assessment of the State of the Baltic Sea Environment" (HELCOM, 1987, 1990; Andersin et al., 1990; Żmudziński et al., 1987) and many other publications. 


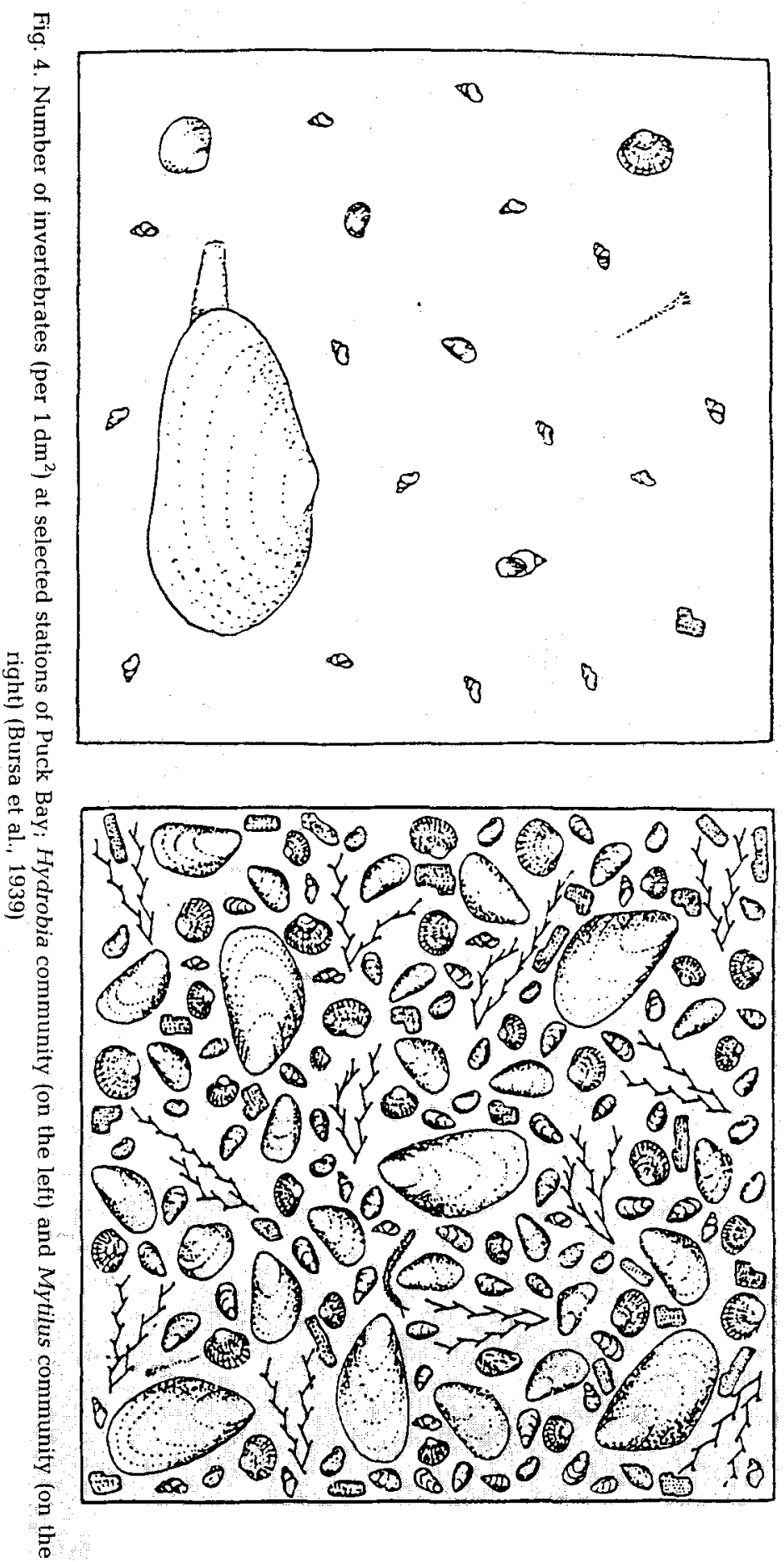


Table 3. Number of macrobenthic stations during the early period of biomass investigations in the southern Baltic. For meaning of symbols see legend to Table 1

\begin{tabular}{|c|c|c|c|c|c|c|c|c|}
\hline \multirow[t]{2}{*}{ Author } & \multirow[t]{2}{*}{ Years } & \multirow[b]{2}{*}{ Arcona } & \multirow[b]{2}{*}{$\begin{array}{l}\text { Born- } \\
\text { holm }\end{array}$} & \multicolumn{2}{|l|}{ Basins } & \multirow[b]{2}{*}{ Gotland } & \multicolumn{2}{|c|}{$\begin{array}{c}\text { Number of } \\
\text { stations }\end{array}$} \\
\hline & & & & Slupsk & Gdańsk & & $\begin{array}{l}\text { Below } \\
40 \mathrm{~m}\end{array}$ & Total \\
\hline Hagmeier & 1925 & $\mathrm{xx}$ & $\mathrm{xx}$ & $\mathrm{xx}$ & $\mathrm{xx}$ & $\mathrm{x}$ & 22 & 39 \\
\hline Hagmeier & 1929 & $x x x$ & $\operatorname{xxxx}$ & $\mathrm{xx}$ & $\mathrm{xx}$ & $\mathrm{x}$ & 55 & 98 \\
\hline Hagmeier & 1931 & $x x$ & $\mathrm{xx}$ & $\mathrm{x}$ & $\mathrm{x}$ & $\mathbf{x}$ & 13 & 41 \\
\hline Demel, Mańkowski & $1948-50$ & $\mathrm{xx}$ & $\mathrm{xxxx}$ & $\mathrm{xxx}$ & $\mathrm{xxxx}$ & $\mathrm{x}$ & 77 & 102 \\
\hline Demel, Mulicki & $1951-52$ & $\mathrm{xx}$ & $\operatorname{xxxx}$ & $\operatorname{xxxx}$ & $\mathrm{xx}$ & $\mathrm{xx}$ & 85 & 102 \\
\hline Demel, Mulicki & $1952-54$ & $\mathrm{xx}$ & $\mathrm{xxx}$ & $\mathrm{xx}$ & $\mathrm{xxx}$ & $\mathrm{x}$ & 64 & 66 \\
\hline Mulicki, Żmudziń. & $1956-57$ & $\operatorname{xxxx}$ & $\mathrm{xxxx}$ & $\operatorname{xxxx}$ & $\operatorname{xxxx}$ & $\operatorname{xxxx}$ & 162 & 191 \\
\hline Löwe & $1955-58$ & $\operatorname{xxxx}$ & $\mathrm{x}$ & & & & 46 & 177 \\
\hline Żmudziński & 1961 & $\mathrm{xx}$ & $\mathrm{xxx}$ & $\mathrm{xx}$ & $\mathrm{xx}$ & $\mathrm{x}$ & 41 & 63 \\
\hline Żmudziński & 1962 & & & & $x \times x x$ & & 31 & 220 \\
\hline Tulkki & $1963-64$ & & $\mathrm{xxx}$ & & & & 22 & 24 \\
\hline Żmudziński & $1963-66$ & $\mathrm{xxx}$ & $\mathrm{xxxx}$ & $\operatorname{xxxx}$ & $\mathrm{xxxx}$ & & 50 & 252 \\
\hline Żmudziński & $1967-68$ & $\operatorname{xxxx}$ & $\mathrm{xxxx}$ & $\operatorname{xxxx}$ & $\operatorname{xxxx}$ & $\mathrm{xxx}$ & 258 & 386 \\
\hline Total & & & & & & & 913 & 1722 \\
\hline
\end{tabular}

\section{LITERATURE CITED}

Andersin, A. B., Lassig, J. \& Sandler, H., 1977. Community structures of soft-bottom macrofauna in different parts of the Baltic. In: Biology of benthic organisms. Ed. by B. F. Keegan, P. O'Ceidigh \& P. J. S. Boaden. Pergamon Press, New York, 7-20.

Andersin, A. B., Lassig, J., Parkkonen, L. \& Sandler, H., 1978. The decline of the macrofauna of the deeper parts of the Baltic Proper and the Gulf of Finland. - Kieler Meeresforsch. (Sonderh.) 4, 23-52.

Andersin, A. B., Cederwall, H., Gosselck, F., Jensen, J. N., Josefsson, A., Lagzdins, G., Rumohr, H. \& Warzocha, J., 1990. Zoobenthos. - Baltic Sea Environ. Proc. 35, 211-275.

Brandt, K., 1893. Die mit der Kurre oder Dredge auf der Expedition gesammelten Tiere. - Jber: Kommn wiss. Unters. dt. Meere. 6, 141-147.

Bursa, A., Wojtusiak, H. \& Wojtusiak, R. J., 1948. Investigations of the bottom fauna and flora in the Gulf of Gdańsk made by using a diving helmet, Part II. - Bull. Acad. pol. Sci. Lett. (B) 2, 213-239.

Bursa, A., Wojtusiak, H. \& Wojtusiak, R. J., 1939. Untersuchungen über die Bodenfauna und Bodenflora der Danziger Bucht unter Anwendung eines Taucherhelms. - Bull. Acad. pol. Sci. Lett. (B) 2, 61-99.

Demel, K., 1925. Animal communities on bottom of the Polish Sea-Part 1. Qualitative investigations. - Spraw. Kom. fizjogr. Kraków 61, 113-146. (In Polish with English summary.)

Demel, K., 1935. Studies of bottom fauna and its distribution in the Polish Baltic Sea waters. Archwm Hydrobiol. Ryb. 9, 239-312. (In Polish with English summary.)

Demel, K. \& Mańkowski, W., 1951. Quantitative investigations on the bottom fauna in the southern Baltic - Pr. morsk Inst. ryb. Gdyni 6, 57-82. (In Polish with English summary)

Demel : K. \& Mulicki, Z, 1954. Quantitative investigations on the biological bottom productivity of the southern Baltic - Pr morsk. Inst ryb. Gdyni 7, 75 126. (In Polish with English summary)

Demel, K. \& Mulicki, Z., 1959. Quantitative investigations on the nearbottom fauna of the southern Baltic. - Pr. morsk. Inst. ryb. Gdyni 10 A, 19-29. (In Polish with English summary.)

Forsman, B, 1956. Notes on the invertebrate fauna of the Baltic. - Ark. Zool. 9, 389-419.

Hagmeier, A., 1926. Die Arbeiten mit dem Petersenschen Bodengreifer auf der Ostseefahrt, April 1925. - Ber dt. wiss. Kommn Meeresforsch. 2, 92-95. 
Hagmeier, A., 1930. Die Bodenfauna der Ostsee in April 1929, nebst einigen Vergleichen mit April und Juni 1926. - Ber. dt. wiss. Kommn Meeresforsch. 5, 156-173.

Hagmeier, A., 1987. Die Bodenfauna der Ostsee. - Mitt. zool. Mus. Univ. Kiel 2 (5), 13-32.

Heinen, A., 1919. Die Nephthyden and Lycoriden der Nord- und Ostsee einschließlich der verbindenden Meeresteile. - Wiss. Meeresunters. (Kiel) 13, 1-88.

HELCOM, 1987. First Periodic Assessment of the State of the Marine Environment of the Baltic Sea Area, 1980-1985; General Conclusions. - Baltic Sea Environ. Proc. 17 A, 1-54.

HELCOM, 1990. Second Periodic Assessment of the State of the Marine Environment of the Baltic Sea, 1984-1988, - Baltic Sea Environ. Proc. 35 A, 1-28.

Hessle, C., 1924. Bottenboniteringar i inre Ostersjon. - Meddn K. Lantbr Styr. 250, 3-53. (In Swedish.)

Järvekülg, A., 1979. Donnaja fauna wostòĉnoj Casti Baltijskogo Morja. - Izd. Balgus, Tallin, 382 pp. (In Russian.)

Jażdżewski, K., 1962. Some notes about bottom fauna of the Puck Bay. - Przegl. zool. 6, (4) 286-290. (In Polish with English summary.)

Jaźdzewski, K., 1971. Ecology of Crustacea in the Bay of Puck. - Acta biol. med. Gdansk 16, 9-77.

Leppäkoski, E., 1969. Transitory return of the benthic fauna of the Bornholm Basin after extermination by oxygen insufficiency. - Cah. Biol. mar. 10, 163-172.

Leppäkoski, E., 1975. Macrobenthic fauna as indicator of oceanization in the southern Baltic. Merentutkimuslait. julk. 239, 280-288.

Löwe, F. K., 1963. Quantitative Benthosuntersuchungen in der Arkonasee. - Mitt. zool. Mus. Berl. 39, 245-349. (In German with English summary.)

Lundbeck, J., 1929. Der Boden der Ostsee an der Küste des Samlandes und seine Bedeutung für die Fischerei. - Mitt. dt. Seefisch.Ver. 45, 274-285.

Michaelsen, W., 1896. Die Polychaetenfauna der deutschen Meere einschließlich der benachbarten und verbindenden Gebiete. - Wiss. Meeresunters. (Helgoland) 2, 1-316.

Meyer, H. A. \& Möbius, K., 1882. Bericht über die Untersuchungen der Danziger Bucht vom 9. bis 15. September 1880. - Jber. Kommn wiss. Unters. dt. Meere 11, 181-184.

Möbius, K., 1873. Die wirbellosen Thiere der Ostsee. - Jber. Kommn wiss. Unters. dt. Meere 1, 97-154.

Möbius, K., 1884. Nachtrag zum Verzeichnis der wirbellosen Tiere der Ostsee. - Jber. Kommn wiss Unters. dt. Meere 4 (2), 61-70.

Mulicki, Z., 1938. Outline of quantitative distribution of bottom fauna along the Polish Baltic Sea coast. - Biul. Sta, morsk. Helu 2, 75-102. (In Polish with English summary.)

Mulicki, Z., 1957. Ecology of the more important Baltic invertebrates. - Pr. morsk. Inst. ryb. Gdyni 9 A, 313-379. (In Polish with English summary.)

Mulicki, Z., 1959. The polychaete Harmothoe sarsi Kinberg and its environments in the Baltic Sea. Pr. morsk. Inst. ryb, 10 A, 163-174. (In Polish with English summary.)

Mulicki, Z., 1962. Ecology of polychaete Nephthys ciliata O.F.M. on the border of the Baltic reach. Pr. morsk. Inst. ryb. 11 A, 59-63. (In Polish with English summary.)

Mulicki, Z., \& Żmudziński, L., 1969. Stock of the zoobenthos in the southern Baltic (in the 1956-1957 period). - Prace morsk. Inst. ryb. Gdyni 15 A, 77-101. (In Polish with English summary.)

Ostrowski, J. \& Żmudziński, L., 1982. Baltic sublitoral zoobenthos. In. Baltic Sea zoobenthos of the sixties. Ed. by Żmudziński. Wyższa Szkola Pedagog. Slupsk 79-107. (In Polish with English summary.)

Petersen, C. G. J., 1914. On the distribution of the animal communities on the sea bottom. - Rep. Dan biol Stn 22, 1-7.

Petersen, C. G. J. \& Jensen, P. B., 1911. Valuation of the sea. I. Animal life of the sea-bottom, its food and quantity. - Rep. Dan. biol Stn 20, 1-81.

Reibisch, J, 1902. Die Ostsee Expedition 1901 IV: Wirbellose Bodentiere, - Abh. dt. SeefischVer. 7, 141-160.

Rumohr, H., 1987. Der Beltrag A. Hagmeiers zur Kenntnis des Benthos der Ostsee. - Mitt. zool. Mus. Univ. Kiel 2 (5), 3-12

Seifert, R, 1938. Die Bodenfauna des Greitswalder Bodden; ein Beitraq zur Ökoloqie der Brackwasserfauna - Z Morph. Ökol. Tiere 34, 220-271. 
Sklower, A., 1930. Die Tierwelt vor der samländischen Ostseeküste und ihr Zusammenschluß zu Lebensgemeinschaften. - Zool. Anz. 92, 254-266.

Skorikow, A. S., 1910. Die Polychaeten und Gephyreen der Ostsee. - Ann. Mus. Zool., Imp. Acad. Sci. St. Petersburg 4 (15), 207-236.

Thulin, G., 1922. Bottenboniteringar i södra Ostersjön i samband med fisktralningar. - Svenska hydrogr.-biol. Kommn. Skr. 6, 1-9. (In Swedish.)

Tulkki, P., 1965. Disappearance of the benthic fauna from Basin of Bornholm (Southern Baltic) due to oxygen deficiency. - Cah. Biol. mar. 6, 445-446.

Wojtusiak, R. J., Kornaś, A., Kornaś, J. \& Franckiewicz, H., 1950. Investigations on the bottom fauna and flora in the Gulf of Gdansk made by using a diving helmet. - Mater. Fizjogr. Kraju 26 1-20.

Wojtusiak, R., Wojtusiak, H., Kałkowski, W., Rumek, A. \& Franckiewicz, H., 1951. Investigations of the bottom fauna and flora in the Gulf of Gdansk made by using a diving helmet, Part IV. - Bull. Acad. Pol., Sci. Lettr. (Ser. B, Sci. nat.) 2, 223-267.

Żmudziński, L., 1967. Zoobenthos of the Gdańsk Bay. - Pr. morsk. Inst. ryb. Gdyni 14 A, 47-80. (In Polish with English summary.)

Żmudziński, L., 1968. Veränderlichkeit der Bodenfauna im südlichen Teile der Ostsee infolge der hydrologischen Veränderungen im letzten Jahrhundert. - Zesz. Nauk. SGGW, Volume 7 of Ser. Zootechn., Ryb. 3, Warszawa, 165-192.

Żmudziński, L., 1971. The increase of the Baltic bottom fauna stocks. - Prace morsk. Inst. ryb. Gdyni (Tom jubil.) 1971, 285-307. (In Polish with English summary.)

Żmudziński, L., 1976. Bottom fauna as an indicator of the advancing eutrophication of the Baltic. Studia Mater. oceanol. 15, 297-306. (Biol. Morza 3) (In Polish with English summary.)

Żmudziński, L., 1978. Variability of species composition and biomass of bottom fauna in the southern Baltic area. In: Produktywność ekosystemu morza Baltyckiego. Ed. by W. Mankowski. Ossolineum, Wroclaw, 143-161. (In Polish with English summary.)

Żmudziński, L., 1982. Baltic shallow-water zoobenthos. In: Baltic Sea zoobenthos of the sixties. Ed. by L. Żmudziński. Wyższa Szkoła Pedagog., Słupsk, 39-78. (In Polish with English summary.)

Żmudziński, L., Gosselck, F., Cederwall, H., Jensen, K. \& Rumohr, H., 1987: Chapter 5-Zoobenthos. In: Baltic Sea Envir. Proc. 17 B, Helsinki, 256-321.

Żmudziński, L. \& Osowiecki, A., 1991. Long-term changes in macrozoobenthos of the Gdańsk Deep. Int. Revue ges. Hydrobiol. 76, 465-471. 